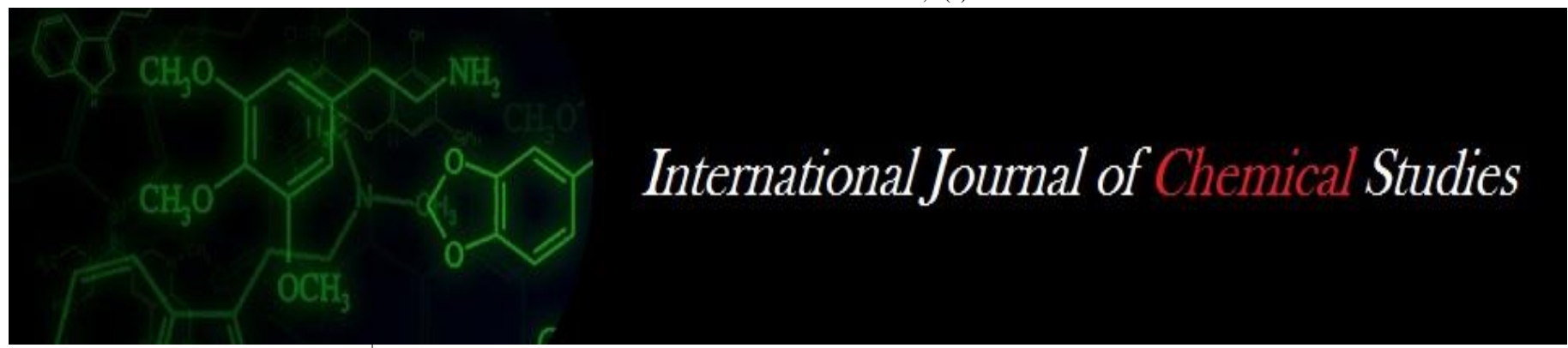

P-ISSN: 2349-8528

E-ISSN: 2321-4902

www.chemijournal.com

IJCS 2020; 8(5): 146-149

(C) 2020 IJCS

Received: 20-06-2020

Accepted: 22-08-2020

\section{Krishna Kumar}

Department of Plant Pathology,

A.N.D.U.A. \& T. Kumarganj,

Ayodhya, Uttar Pradesh, India

\section{SK Pande}

Department of Plant Pathology,

A.N.D.U.A. \& T. Kumarganj,

Ayodhya, Uttar Pradesh, India

Ghanshyam Verma

Department of Plant Pathology, C.B.L. Degree College Rasulpur,

Dhaurahara, Lakhimpur,

Uttar Pradesh, India

\section{Popin Kuma}

Department of Plant Pathology,

S.V.P.U.A. \&T. Modipuram

Meerut, Uttar Pradesh, India

\section{Sandeep Kumar}

Department of Plant Pathology,

School of Agriculture,

Uttaranchal University, Prem

Nagar, Dehradun, Uttarakhand, India
Corresponding Author:

Krishna Kumar

Department of Plant Pathology,

A.N.D.U.A. \& T. Kumarganj,

Ayodhya, Uttar Pradesh, India

\section{History and objective of plant quarantine in India: A review}

\author{
Krishna Kumar, SK Pande, Ghanshyam Verma, Popin Kumar and \\ Sandeep Kumar
}

DOI: https://doi.org/10.22271/chemi.2020.v8.i5b.10292

\begin{abstract}
Quarantine is derived from Latin word 'Quarandum' which means forty (40) days. It is a system to define which was used in case of ship during from country affected from pathogen cholera. In India the Destructive Insects and Pests Act was pass in 1914 (DIP act) for quarantine regulation. The term 'Quarantine' came to be only used for the inhibition and the practices related with it. Important of pathogen free country with efficient plant quarantine service so that instruction and treatment is obtaining planting material from the free sheet non source with the selected country. Untreated seed so that detected of seed borne pathogen is seed pathologist have looking healthy seed free from often and official certification of freedom from pest and diseases from the exported country.
\end{abstract}

Keywords: Quarantine, epidemics, pests and diseases

\section{Introduction}

Quarantine is derived from Latin word 'Quarandum' which means forty (40) days. It is a system to define which was used in case of ship during from country affected from pathogen cholera. In India the Destructive Insects and Pests Act was pass in 1914 (DIP act) for quarantine regulation (Reddy, 2010) ${ }^{[8]}$. The crew and the traveler used to be helpless to remain isolated on board for enough periods to permit the diseases to develop and detect. The purpose of the health authorities was to establish adequate detention period. The term 'Quarantine' came to be only used for the detention and the practices connected with it. The term got associated from the human disease field to the animal disease field and on adopted to cover protective methods for the exclusion of pests and diseases of agricultural and horticultural crops.

Plant Quarantine rule are promulgated by the national and the state governments to prevent the introduction and spread of harmful pests and pathogens. Protection of the plant and plant products by quarantine but only become the governments at the turn of this century, following a series of catastrophic pest and diseases epidemics in different parts of the world (Rai, et al., 2014) ${ }^{[6 a]}$. In addition to endemic problems there are many crop pests which are implant India from other countries therefore in earlier years India did not have an functional control measure (Plant Quarantine) system to stop the introduction of exotic pests, diseases and weeds. Quarantine plan are the first line of safety in plant protection and they should be stimulate in every way actual in every country (Webster, 1985) ${ }^{[9]}$.

In a survey of pests named in quarantine regulation in 125 countries, 614 were species of insects and mites (Kahn, 1983) ${ }^{[2]}$. Cottony cushion scale, woolly aphid, San Jose scale, golden cyst nematode of potatoes, the giant African snail are some exotic pest introduced into our country and cause spacious damage (Khan, et al., 2017) ${ }^{[3]}$. On the other hand, the pathogen finds a large amount of available sensitive tissue on which it can treat and multiply unchecked. Few of the worst plant disease epidemics, e.g., the downy mildew of grapes in Europe and the bacterial canker of citrus, chestnut blight, Dutch elm disease, and soybean cyst nematode in the United States, are all diseases caused by pathogens that were introduced from abroad. It has been estimated, of soybean rust were introduced into the United States it would result in losses to consumers and other sectors of the U.S. economy of several billion dollars per year $\left(\right.$ Agrios, 2005) ${ }^{[1]}$. 


\section{History of Plant Quarantine in India}

The consciousness to quarantine measures in India started in early $20^{\text {th }}$ century when the Indian Government in 1906, ordered compulsory fumigation of imported cotton bales to prevent the introduction of the dreaded Mexican cotton boll weevil (Antonymous grandis). On February 3, 1914 Comprehensive Plant Quarantine Act, known as Destructive Insects and Pests Act, (DIP Act) become operative. Over the years the DIP Act was revised and correct separate times. After some time needs to be periodically observe and improve to conspire the growing requirements of liberalized trade under the WTO. In 1946, the Directorate of Plant Protection, Quarantine and Storage, under the ministry of Food and Agriculture were set up. In 1946, Plant quarantine activity stared with the onset of plant introduction scheme in the Botany Division at Indian Agricultural Research Institute (IARI) New Delhi. In October 1949, the Directorate started its quarantine activities at Bombay seaport. On December 25,
1951 the first plant Quarantine and fumigation station in India was formally inaugurated. In August, 1976 the National Bureau of Plant Genetic Resource (NBPGR) was created. In 1978, the Division of Plant Quarantine was making with Entomology, Plant Pathology and Nematology sections. In 1981 post entry quarantine of imported wheat, barley and triticale started in isolation nursery. In 1983 the post entry quarantine for detection of seed transmitted viruses in exotic legumes started. In 1984 Plants, Fruits and Seeds (PFS) (Regulation of Import into India) order issued under DIP Act. In 1988 New Policy on Seed Development (NPSD) announced, resulting in increased import of seed material. In 1989 Plants, Fruits and Seeds Order (1984) revised to meet the requirements of NPSD and increasing imports. In 2003 Plant Quarantine (Regulation of Import into India) Order. The development of new Plant Quarantine (Regulation of Import into India) reflects the main plant quarantine care of the Government of India (Laxmi et al., 2014) ${ }^{[6 b]}$.

Table 1: Pests and diseases which have been introduced world wise

\begin{tabular}{|c|c|c|c|c|}
\hline S. No. & Pests and diseases & In & From & Year \\
\hline 1. & Late blight of potato (Phytophthora infestans) & Europe & S. America & 1830 \\
\hline 2. & Powdery mildew of grape (Uncinula necator) & England & USA & 1845 \\
\hline 3. & Grape Phylloxera (Phylloxera vitifoliae) & France & USA & 1845 \\
\hline 4. & Downey mildew of grape (Plasmopara viticola) & France & USA & 1878 \\
\hline 5. & Golden nematode of potato (Heterodera rostochinensis) & USA, Mexico & Europe & 1881 \\
\hline 6. & Mexican boll weevil (Anthonomus grandis) & USA & C. America & 1892 \\
\hline 7. & Chestnut blight (Cryphonectria parasitica) & USA & Asia & 1904 \\
\hline 8. & Citrus canker (Xanthomonas citri) & USA & Asia & 1907 \\
\hline 9. & Blister rust of pine (Cronartium ribicola) & USA & Europe & 1910 \\
\hline 10. & Fire blight of apple (Erwinia amylovora) & New Zealand & N. America & 1919 \\
\hline 11. & Onion smut (Urocystis cepulae) & Switzerland & France & 1924 \\
\hline 12. & Dutch elm (Ceratostomella ulmi) & USA & Holland & $1928-30$ \\
\hline 13. & Bacterial canker of tomato (Cornebacterium michiganensis) & UK & USA & 1942 \\
\hline 14. & Coffee rust (Hemillia vastatrix) & Brazil & Africa and Asia & 1970 \\
\hline
\end{tabular}

(Kothekar, 1970; Mathys and Baker, 1980) ${ }^{[4,6]}$

\section{Importance}

The entry of a single exotic insect or disease and its establishment in the new environment continues to cause great, national loss (table 2) till such time it is brought under effective control. In certain cases a country has to spend a few million rupees before success in controlling the introduced insect pest or disease is achieved.

Table 2: Exotic pests can cause huge losses to our crop wealth

\begin{tabular}{|c|c|c|c|c|c|}
\hline S. No. & Diseases & Host & Introduced from & Country & Losses caused \\
\hline 1. & Canker & Citrus & Japan & U.S.A & $\$ 13$ million; 19.5 million trees destroyed \\
\hline 2. & Dutch elm & Elm & Holland & U.S.A. & $\$ 25$ million $-\$ 50,000$ disease million \\
\hline 3. & Blight & Chestnut & Eastern Asia & U.S.A. & $\$ 100-1000$ million \\
\hline 4. & Powdery mildew & Grapevine & U.S.A & France & $80 \%$ in wine production \\
\hline 5. & Downy mildew & Grapevine & U.S.A & France & \$50,000 million \\
\hline 6. & Bunchy top & Banana & Sri Lanka & India & Rs.4 crores \\
\hline 7. & Wart & Potato & Netherlands & India (1953) & 2500 acres infected \\
\hline 8. & South American leaf blight & Rubber & Guiana & Dutch-Brazil & 40,000 trees destroyed \\
\hline 9. & Flage smut & Wheat & Australia & India (1906) & - \\
\hline 10. & Blue mold & Tobacco & U.K. & Europe & \$50 million \\
\hline 11. & Golden nematodes & Potato & Europe & India (1961) & - \\
\hline 12. & Paddy blast & Rice & South Europe & Asia (1918) & - \\
\hline
\end{tabular}


Table 3: Plant diseases introduced into India from foreign countries

\begin{tabular}{|c|c|c|c|c|}
\hline S. No. & Disease & Host & First record & Introduction from \\
\hline \begin{tabular}{|l|l}
1. & \\
\end{tabular} & Leaf rust (Hemileia vastarix) & Coffee & 1879 & Sri Lanka \\
\hline 2. & Late blight (Phytophthora infestans) & Potato Tomato & 1883 & Europe \\
\hline 3. & Rust (Puccinia carthami) & Chrysanthemum & 1904 & Japan or Europe \\
\hline 4. & Flag smut(Urocystis tritici) & Wheat & 1906 & Australia \\
\hline 5. & Downy mildew(Plasmopara viticola) & Grapevine & 1910 & Europe \\
\hline 6. & Downy mildew (Pseudoperonospora cubensis) & Cucurbits & 1910 & Sri Lanka \\
\hline 7. & Downy mildew(Sclerospora philippinensis) & Maize & 1912 & Java \\
\hline 8. & Black rot (Xanthomonas compestris) & Crucifers & 1929 & Java \\
\hline 9. & Foot rot (Fusarium moniliforme var. majus) & Rice & 1930 & South East Asia \\
\hline 10. & Leaf spot(Phyllachora sorghi $)$ & Sorghum & 1934 & South Africa \\
\hline 11. & Powdery mildew(Oidium heveae) & Rubber & 1938 & Malaya \\
\hline 12. & Blank Shank & Tobbaco & 1938 & Holland \\
\hline 13. & Fire blight Pear and other (Erwinia amylovora & Pomes & 1940 & England \\
\hline 14. & Crown-gall and hairy root (Agrobacterium tumefaciens, A. rhizogenes) & Apple, Pear & 1940 & England \\
\hline 15. & Bunchy Top Virus & Banana & 1940 & Sri Lanka \\
\hline 16. & Canker (Sphaeropsis spp.) & Apple & 1943 & Australia \\
\hline 17. & Wart (Synchytrium endobioticum) & Potato & 1953 & Netherlands \\
\hline 18. & Bacterial blight & Rice & 1959 & Philippines \\
\hline 19. & Golden nematodes & Potato & 1961 & Europe \\
\hline 20. & San Jose scale & Apple & 1900 & Italy \\
\hline 21. & Wooly aphid & Apple & 1928 & Australia \\
\hline 22. & Downy mildew & Sunflower & 1985 & Australia \\
\hline
\end{tabular}

\section{Agencies involved in plant quarantine}

The authority to instrument the quarantine regulations framed under DIP Act rests mainly with the Directorate of Plant Protection, Quarantine \& Storage, under the Ministry of Agriculture. This organization handles minority import and export of seed and planting material for commercial purpose. Under this organization 19 seaports, 12 airports and 14 land frontiers and 5 regional head quarter are such as New Delhi, Chennai, Calcutta, Mumbai and Amritsar functioning. These are the recognized ports for entries for import of plant and plant material. The names and places of the ports and stations are as follows.

Points of Entry for Import of plants/ plant materials and other articles decesion under Plant Quarantine (Regulation of Import into India) Order, 2003

\section{A. Seaports - Place State / Union territory}

1. Alleppey- Kerala 2. Bhavnagar-Gujarat 3. Calcutta-West Bengal 4. Calicut-Kerala 5. Chennai-Tamil Nadu 6. CochinKerala 7. Cuddalore-Tamil Nadu 8. Goa-Goa 9. GopalpurOrissa 10. Haldia-West Bengal 11. Jamnagar-Gujarat 12. Beypore-Kerala 13. Kakinada- Andhra Pradesh 14. KandlaGujarat 15. Karwar-Karnataka 16. Krishnapattinam- Andhra Pradesh 17. Machlipatnam-Andhra Pradesh 18. MandviGujarat 19. Manglore-Karnataka.

\section{B. Airports}

1. Amritsar-Punjab 2. Bangalore-Karnataka 3. Calcutta-West Bengal 4. Chennai-Tamil Nadu 5. Hyderabad-Andhra Pradesh 6. Mumbai-Maharashtra 7. New Delhi-New Delhi 8. PatnaBihar 9. Tiruchirappalli-Tamil Nadu 10. TrivananthapuramKerala 11. Varanasi-Uttar Pradesh 12. Guwahati-Assam

\section{Land frontiers}

1. Amritsar Railway Station-Punjab 2. Agartala-Tripura 3. Attari Railway Station-Punjab 4. Attari-Wagah Border-Punjab 5. Bongaon Benapol Border-West Bengal 6. Gede Road Railway Station-West Bengal 7. Jogbani-Bihar 8. MorehManipur 9. Pantitanki-West Bengal 10. Raxual-Bihar 11. Rupadia-Uttar Pradesh 12. Sonauli-Uttar Pradesh 13. Banbasa-Uttar Pradesh 14. Zokhwathar-Mizoram.

\section{Objectives of Plant Quarantine}

1. To prevent the introducing of dangerous diseases and pest are new race of a pathogen at their spread in the country.

2. The inspection of imported agricultural commodities for preventing the introduction of exotic pests and diseases inimical to Indian fauna and flora through implementation of DIP Act, 1914 and the Plant Quarantine (Regulation of Import into India) Order, 2003 issued there under.

3. Inspection of plants and plant material meant for export as per the requirements under International Plant Protection Convention (IPPC) 1951 of FAO to facilitate pest free trade.

4. The detection of exotic pests and diseases for their containment by adopting domestic quarantine regulations.

\section{Guidelines for importance of germplasms}

1. Important of pathogen free country with efficient plant quarantine service so that instruction and treatment is obtaining planting material from the free sheet non source with the selected country.

2. Obtain untreated seed so that detected of seed borne pathogen is seed pathologist have looking healthy seed free from often and official certification of freedom from pest and diseases from the exported country.

3. The smallest amount of planting materials, the small amount of less chance of carrying infection carefully unarrivable and treat.

4. In other precaution are not adequate the material to post internal quarantine. There are total four agencies which have been a single to responsibility of quarantine processing of plants and planting material.

5. National Bureau of Plant Genetic Resources, (NPBGR)New Delhi.

6. Forest Research Instiute, (FRI) Dehradun (Uttarakhand).

7. Botanical Survey of India (BIS) - Calcutta. 
The ongoing activities assigned under the scheme include

1. To issue import permits with additional declarations and special conditions to facilitate safe imports of agricultural products.

2. To undertake quarantine inspection and laboratory testing of plants and plant material to ensure freedom from exotic pests.

3. To undertake Phytosanitary Crtification (issuance of Phytosanitary Certificates (PSCs); 150 Nos. of Officers from Central/ State/ UT Governments have been authorized for this purpose.

4. To undertake fumigation/disinfestations/disinfections of commodities to control infestation/infection.

5. To undertake certification of post-entry quarantine facilities and inspection of imported growing plants and plant material; 41 Nos. of Inspection Authorities have been designated.

6. To support Export market access for India's Agriculture products from the Phytosanitary point of view.

7. To facilitate safe global trade in agriculture by assisting the producers and exporters by providing a technically competent and reliable Phytosanitary certificate system to meet the requirements of trading partners.

8. To provide Grants-in-aid to Designated Inspection Authorities to meet the travel expenses and also to State PSC issuing authorities for equipping them with minimal equipments required for export inspection/certification.

\section{Conclusion}

The purpose of the health authorities was to establish adequate detention period. The term 'Quarantine' came to be only used for the detention and the practices connected with it. Plant Quarantine regulations are promulgated by the national and the state governments to prevent the introduction and spread of harmful pests and pathogens.

\section{References}

1. Agrios GN. Plant Pathology, Fifth Edition, Elsevier publication, 2005, 295-296.

2. Kahn RP. Safe guarding the international exchange of plant germplasm. In: 10th International Congress of Plant Protection. Proceedings of a conference held at Brighton, England. 1983; 2(20-25):866-872.

3. Khan HH, Verma SS, Saleem M, Verma SK, Usmani TA, Naz $\mathrm{H}$ et al. Role and history of plant quarantine in India- A review. International Journal of Chemical Studies. 2017; 5(6):2034-2037.

4. Kothekar VS. In: A Hand Book of Pests, Disease and Weeds of Quarantine Significance. Amerind Publishing Co. Pvt. Ltd., New Delhi, 1970, 13-103.

5. Mathys G, Baker EA. Annual Review of Phytopathology, 1980; 18:85-89.

6. Rai VL, Geetanjalym, Sharma P. Plant Quarantine: An Effective Strategy of Pest Management in India. Research Journal of Agriculture and Forestry Sciences. 2014; 2(1):11-16.

7. Reddy D. Applied Entomology, New Vishal Publications, 2010; 75 .

8. Webster HS. In: Plant Protection an Integrated Interdisciplinary Approach. Kalyani Publishers, New Delhi. 1985; 19-24. 